\title{
Dynamics and GPR stratigraphy of a polar rock glacier on James Ross Island, Antarctic Peninsula
}

\author{
Kotaro FUKUI, ${ }^{1}$ Toshio SONE, ${ }^{2}$ Jorge A. STRELIN, ${ }^{3,4}$ Cesar A. TORIELLI, ${ }^{3}$ Junko MORI, ${ }^{2}$ \\ Yoshiyuki FUJII \\ ${ }^{1}$ National Institute of Polar Research, Kaga 1-9-10, Itabashi-ku, Tokyo 173-8515, Japan \\ E-mail: fukui@nipr.ac.jp \\ ${ }^{2}$ Institute of Low Temperature Science, Hokkaido University, Sapporo 060-0819, Japan \\ ${ }^{3}$ Facultad de Ciencias Exactas Fisicas y Naturales, Universidad Nacional de Córdoba, Av. Velez Sarsfield 1611, \\ X5016 GCA Córdoba, Argentina \\ ${ }^{4}$ Instituto Antártico Argentino, Cerrito 1248, C1010AAZ Buenos Aires, Argentina
}

\begin{abstract}
We describe field measurements (ground-penetrating radar (GPR), geodetic survey and ice-core drilling) to provide new information on the movement mechanism and internal structure of a polar rock glacier on James Ross Island, Antarctic Peninsula. We collected GPR data along longitudinal and transverse profiles. The longitudinal GPR profiles identify inter-bedded debris-rich layers that dip up-glacier, similar to the thrust structures in the compression zone of a valley glacier. The transverse GPR profiles indicate a syncline structure inclined towards the central part of the rock glacier, resembling the transverse foliation of a valley glacier. The stratigraphy of two boreholes shows that the rock glacier consists primarily of bubbly ice with thin debris-rich layers, an internal structure similar to the 'nested spoons' structure common in the interior of valley glaciers. These results indicate that the glacier motion is controlled by shear movement, common in valley glaciers. The geodetic survey confirms that flow velocities decrease towards the lower part of the rock glacier. Such heterogeneous movement causes longitudinal compression and forms thrusts which then create the debris-rich layer by uplifting basal ice and debris. Pushing of the upstream ice against the downstream ice bends the surface layers, forming transverse ridges on the rock glacier surface.
\end{abstract}

\section{INTRODUCTION}

Rock glaciers are tongue- or lobate-shaped debris features that resemble small valley glaciers and move downslope because of the deformation of the ice or ice-cemented sediments (e.g. Wahrhaftig and Cox, 1959; Benn and Evans, 1998; Haeberli and others, 2006). Rock glaciers commonly exhibit multiple ridges perpendicular to the direction of flow on their surface, and a steep frontal slope. They are widely distributed in the permafrost zones of high mountains, polar regions and on Mars (e.g. Barsch, 1996; Colaprete and Jakosky, 1998; Humlum, 1998; Baker, 2003; Degenhardt and Giardino, 2003; Whalley and Azizi, 2003). Rock glaciers are generally classified into talus- and glacierderived, implying non-glacier (periglacial) and glacier types, respectively (e.g. Humlum, 1998, 2000). A talus-derived rock glacier is completely covered with debris and is connected to a talus slope. A glacier-derived rock glacier is comprised of a clean ice trunk surrounded by an extensive area of debris-covered ice (e.g. Humlum, 2000).

On James Ross Island, Antarctic Peninsula, polar rock glaciers are significant features, playing an important role in debris transport in ice-free areas. Chinn and Dillon (1987) described a glacier-derived rock glacier on northwest James Ross Island as a debris-covered polar glacier. They observed the exposed ice stratigraphy and hypothesized that the transition from wet- to dry-based conditions at the glacier sole was a powerful mechanism for entraining debris into the glacier and for lifting debris to the surface. Strelin and Malagnino (1992) studied the rock glaciers on James Ross Island and divided them into two types - lobate- (talusderived) and tongue-shaped (glacier-derived) - based on their dimensions, proportions of accumulation and ablation zones, and lithological composition. They also discussed the possible genesis of many of these rock glaciers. One, designated Tumbledown Norte (Fig. 1), was described by Strelin and Malagnino (1992) as glacier-derived, whereas Lundqvist and others (1995) described the same rock glacier as talus-derived. Strelin and Sone (1998) studied the morphogenesis of a glacier-derived rock glacier (Lachman II rock glacier) in Lachman Crags. They supposed that the outlet glacier from Lachman Crags had advanced during the Little Ice Age (LIA). After the LIA, the rock glacier was considered to have developed principally by basal till extrusion through climate-controlled longitudinal oscillation of the 'regelation zone' (Strelin and Sone, 1998).

We provide new detailed information on the internal structure and movement mechanism of Tumbledown Norte rock glacier (TNRG) based on field data from groundpenetrating radar (GPR), geodetic survey and ice-core drilling, and we attempt to determine whether it is of talus or glacial origin.

\section{STUDY AREA}

James Ross Island $\left(64^{\circ} \mathrm{S}, 58^{\circ} \mathrm{W}\right)$ is located on the eastern side of the Antarctic Peninsula (Fig. 1). Its geology is dominated by Cretaceous sediments and Tertiary volcanic rocks (Bibby, 1966). A single ice cap with a central dome, Dalinger Dome, reaching $1640 \mathrm{~m}$ a.s.l. covers the main part of the island. Only $20 \%$ of the island is ice-free. Large icefree areas are situated in the northwestern part of the island and along the western coast, and numerous rock glaciers 


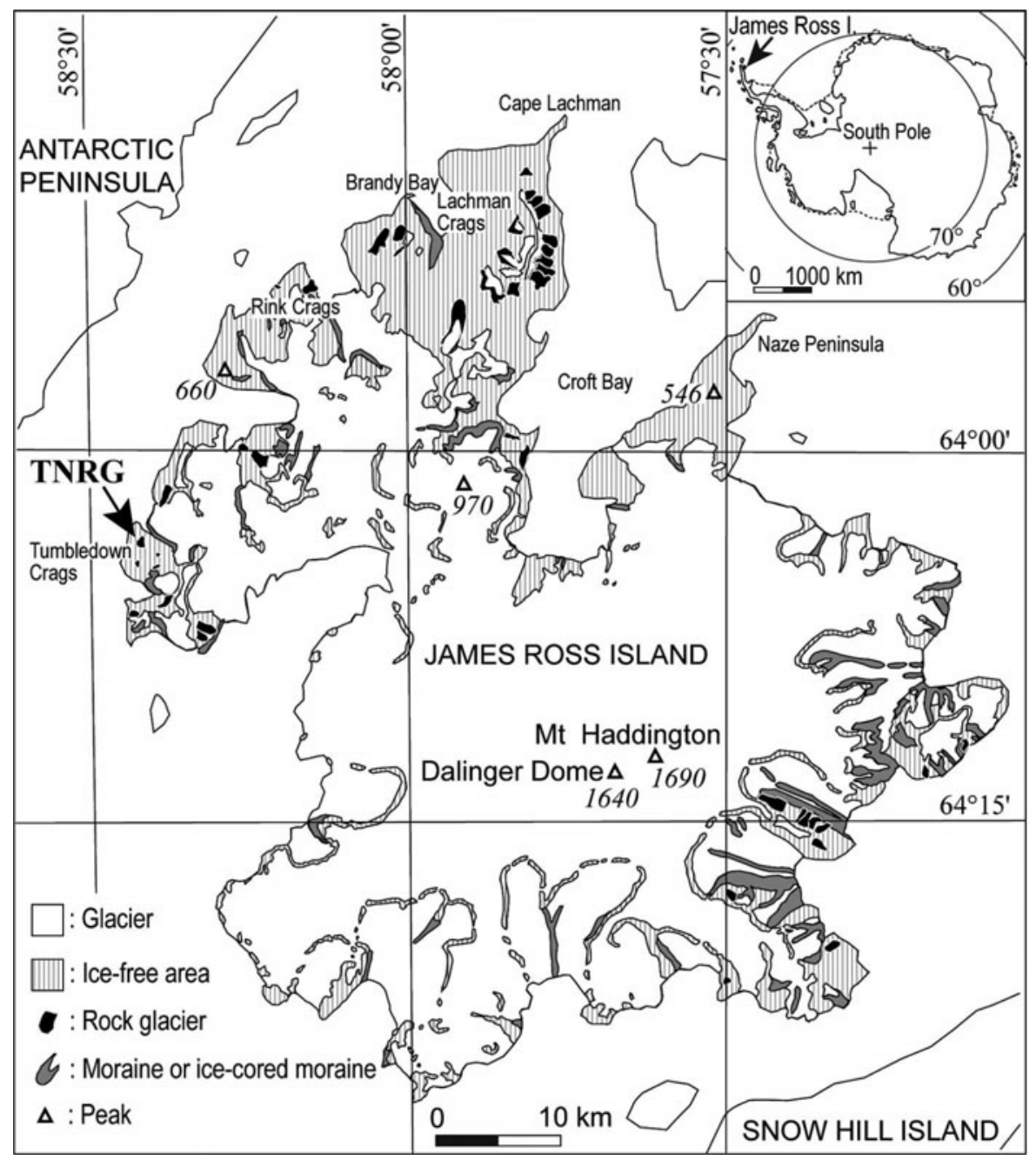

Fig. 1. Distribution of rock glaciers on James Ross Island, Antarctic Peninsula (simplified from Strelin and Malagnino, 1992). TNRG: Tumbledown Norte rock glacier.

and periglacial landforms occur in these areas (Fukuda and others, 1992; Strelin and Malagnino, 1992; Sone and Strelin, 1997; Strelin and others, 2006).

Several Holocene glacier advances have been identified on James Ross Island from the stratigraphy of glaciomarine sediments and till. Hjort and others (1997) reported that the areas that are presently ice-free emerged slightly before $7400 \mathrm{BP}$, and glacier readvance occurred at $4600 \mathrm{BP}$ on the Naze Peninsula and in Brandy Bay. Strelin and others (2006) reported that ice-free areas emerged $9400-7600 \mathrm{BP}$, and major glacier readvances occurred at 6500, 4900-4400 and 3900 BP in the Lachman Crags and Rink Crags areas.

TNRG is located in the western coastal area (Tumbledown Crags area; Fig. 1) of James Ross Island (Strelin and Malagnino, 1992). It has the appearance of a talus-derived rock glacier and is connected to a talus slope (Fig. 2). It is approximately $570 \mathrm{~m}$ long and $300 \mathrm{~m}$ wide, and stretches from south to north. An old rock glacier extends from the northeast side of TNRG. The altitudes of TNRG toe and top are 50 and $150 \mathrm{~m}$ respectively, and the surface has an average slope of $10-11^{\circ}$. The surface debris on the upper part of TNRG is only $0.3-0.4 \mathrm{~m}$ thick, whereas on the lower part it can exceed $1 \mathrm{~m}$. Multiple transverse ridges on the surface are arranged in concentric circles.

Mean annual air temperature for the period 2003-05, from an automatic weather station at $89 \mathrm{~m}$ a.s.l. near the front of the glacier, was $-6.2^{\circ} \mathrm{C}$. The annual precipitation at Marambio base, Argentina, located $85 \mathrm{~km}$ east of the study area was $330 \mathrm{~mm}$ in 2004 and 2005. The equilibrium-line altitude at James Ross Island varies greatly because of winddrifted snow accumulation and isolation. It reaches 200$500 \mathrm{~m}$ a.s.l., with some parts as low as sea level (e.g. in the calving glaciers of the southern part (Strelin and Malagnino, 1992)).

\section{METHODS \\ Geodetic survey}

Geodetic surveys of TNRG were conducted to identify rock glacier activity (Fig. 3b). The positions of nine survey points on TNRG were established in February 2001 by a traverse survey using a total station (GTS701; Topcon Corp., Tokyo, Japan). Repeat surveys were conducted in January 2004. The error of the geodetic surveys was assumed to be $<0.03 \mathrm{~m}$ based on differences between measured distances and distances calculated by triangulation.

\section{GPR sounding}

We used a Noggin 250 GPR system (Sensor and Software Inc., Mississauga, Ontario, Canada). The central frequency of the device is $250 \mathrm{MHz}$. Previous studies of GPR soundings on rock glaciers generally used lower-frequency antennas 
Table 1. Dynamics and ice thickness of TNRG

\begin{tabular}{lcccc}
\hline $\begin{array}{l}\text { Survey } \\
\text { point }\end{array}$ & $\begin{array}{c}\text { Inclination, } \\
\alpha\end{array}$ & $\begin{array}{c}\text { Horizontal } \\
\text { displacement, } U_{0}\end{array}$ & $\begin{array}{c}\text { Surface } \\
\text { lowering } \\
\mathrm{m} \mathrm{a}^{-1}\end{array}$ & $\begin{array}{c}\text { Ice thickness, } \\
\mathrm{m}\end{array}$ \\
\hline 4 & 0 & $\mathrm{~m} \mathrm{a}^{-1}$ & $\mathrm{~m}$ \\
5 & 6 & 0.06 & 0.03 & 38 \\
6 & 10 & 0.15 & 0.02 & 32 \\
7 & 10 & 0.15 & 0.04 & 32 \\
8 & 10 & 0.17 & 0.02 & 33 \\
9 & 10 & 0.12 & 0.03 & 30 \\
10 & 11 & 0.18 & 0.06 & 31 \\
11 & 11 & 0.15 & 0.07 & 29 \\
12 & 11 & 0.16 & 0.05 & 30 \\
\hline
\end{tabular}

such as 25 or $50 \mathrm{MHz}$ in order to sample down to the glacier sole (e.g. Berthling and others, 2000; Isaksen and others, 2000; Degenhardt and Giardino, 2003); however, Berthling and others (2000) pointed out the lack of vertical resolution of these lower-frequency antennas. Thus, we used a higherfrequency antenna. GPR profiles were recorded every $0.05 \mathrm{~m}$, triggered by a distance wheel, in a $600 \mathrm{~ns}$ time window. We measured one longitudinal and two transverse GPR profiles in January 2006 (Fig. 3a). The longitudinal GPR profile (454 $\mathrm{m}$ long) extended along the central flowline (north-south) of TNRG. The transverse GPR profiles were taken in the middle (159 $\mathrm{m}$ long) and upper (187 m long) sections.

The GPR profiles were processed using Radpro 3.4 software for Windows (Korea Institute of Geoscience and Mineral Resources, Daejeon, Korea). Radar-wave velocity for the interior part of the rock glacier was measured using hyperbolic fitting. We performed gain recovery, normal move-out (NMO) correction, frequency-wavenumber (F-K) migration and topographical correction. The processed data were bandpass-filtered at frequencies of 125, 200, 300 and $375 \mathrm{MHz}$ to remove noise. Topographical data for TNRG were obtained from a level survey.

In the upper part of the rock glacier, we found an ice exposure (Fig. 3a) that was approximately $12 \mathrm{~m}$ long and $3 \mathrm{~m}$ high, running parallel (north-south) to the longitudinal GPR profile. The ice exposure resulted from erosion by a stream on the upper part of TNRG. We sketched the stratigraphy of the exposed ice in mid-January 2005 and compared its stratigraphy with that of the GPR.

\section{Ice-core drilling}

Two shallow ice cores were drilled in the frontal $(\mathrm{BH} 1)$ and upper $(\mathrm{BH} 2)$ parts of TNRG in February 2004 using a portable boring machine (Fig. 3a). The $\mathrm{BH} 1$ and $\mathrm{BH} 2$ ice cores were 4.7 and $4.1 \mathrm{~m}$ long, respectively. We sketched the stratigraphy of the ice cores. We also measured temperature in the top $2 \mathrm{~m}$ of the boreholes using a digital thermometer (testo110; testo AG, Lenzkirch, Germany) at a resolution of $0.1^{\circ} \mathrm{C}$ and an accuracy of $\pm 0.2^{\circ} \mathrm{C}$.

\section{RESULTS AND DISCUSSION}

\section{Geodetic survey}

Based on the geodetic surveys from 2001 to 2004, we confirmed that the TNRG was active (Fig. $3 b$ ). The flow vectors
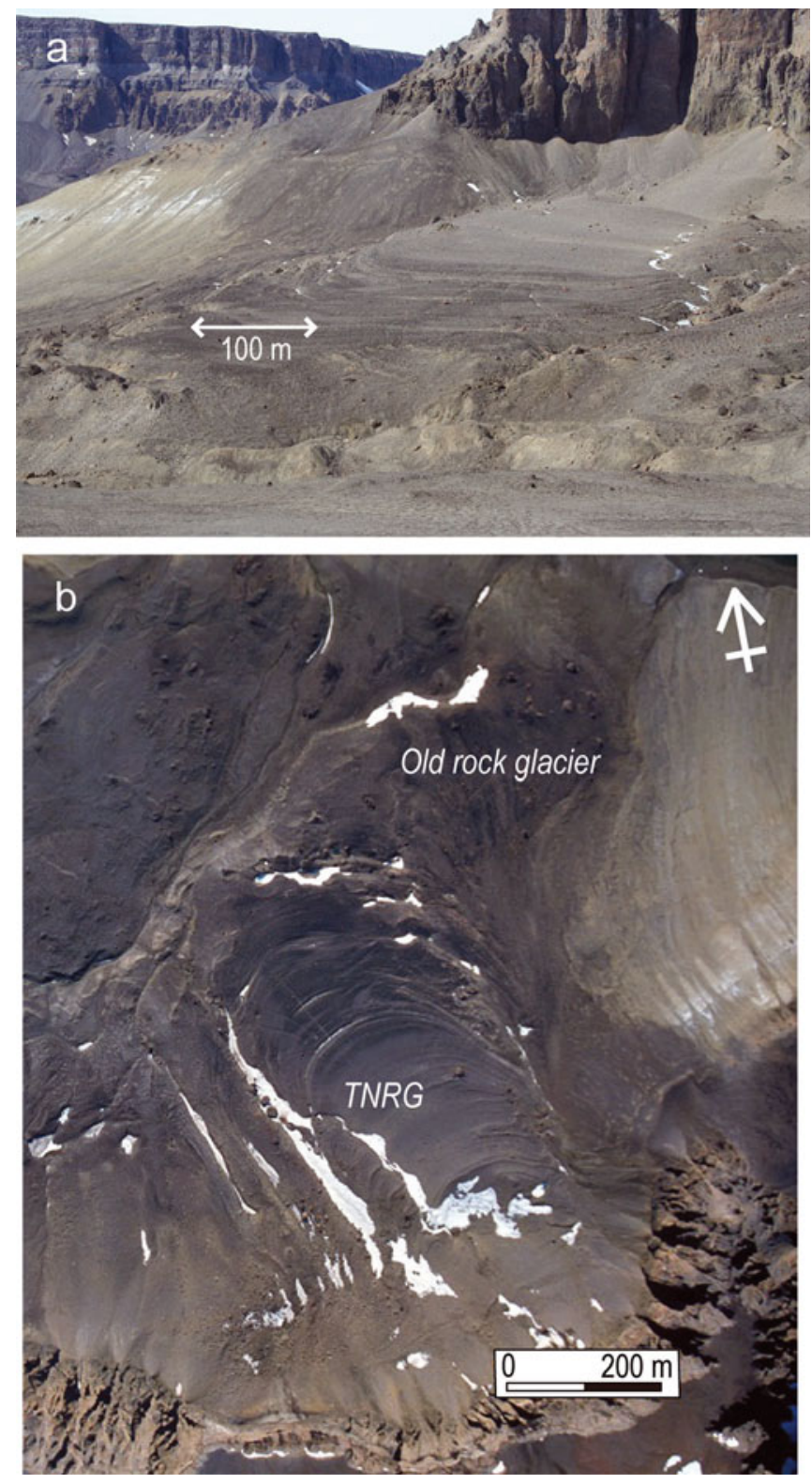

Fig. 2. (a) Multiple transverse ridges on the surface of TNRG; and (b) aerial photograph of the rock glacier.

were approximately normal to the trends of surface ridges (Figs $2 \mathrm{~b}$ and $3 \mathrm{~b}$ ). The horizontal displacements at survey points $6,7,9$ and 12, which were arranged along the central flowline, were $0.15,0.17,0.18$ and $0.23 \mathrm{~m} \mathrm{a}^{-1}$, respectively (Table 1). The displacements indicated that flow velocities decreased toward the lower part of TNRG. The horizontal displacements at survey points 7,9 and $12\left(0.17-0.23 \mathrm{~m} \mathrm{a}^{-1}\right)$ were greater than those at survey points 5, 8, 10 and 11 $\left(0.12-0.16 \mathrm{~m} \mathrm{a}^{-1}\right)$. This indicated that flows were greater at the rock glacier center than near its margin. The surface elevation of large parts of TNRG decreased by $<0.07 \mathrm{~m} \mathrm{a}^{-1}$ (Table 1). The old rock glacier (Fig. 2b) was considered stagnant because the horizontal displacement at survey point 4 was only $0.06 \mathrm{~m} \mathrm{a}^{-1}$.

As stated by Strelin and Sone (1998), it is often assumed that rock glacier flow follows glacier-ice deformation without basal slip (e.g. Potter, 1972; Whalley and Martin, 1992). If the surface movement and surface inclination of a glacier are known, the thickness $(h)$ of the glacier, in $\mathrm{m}$, is 

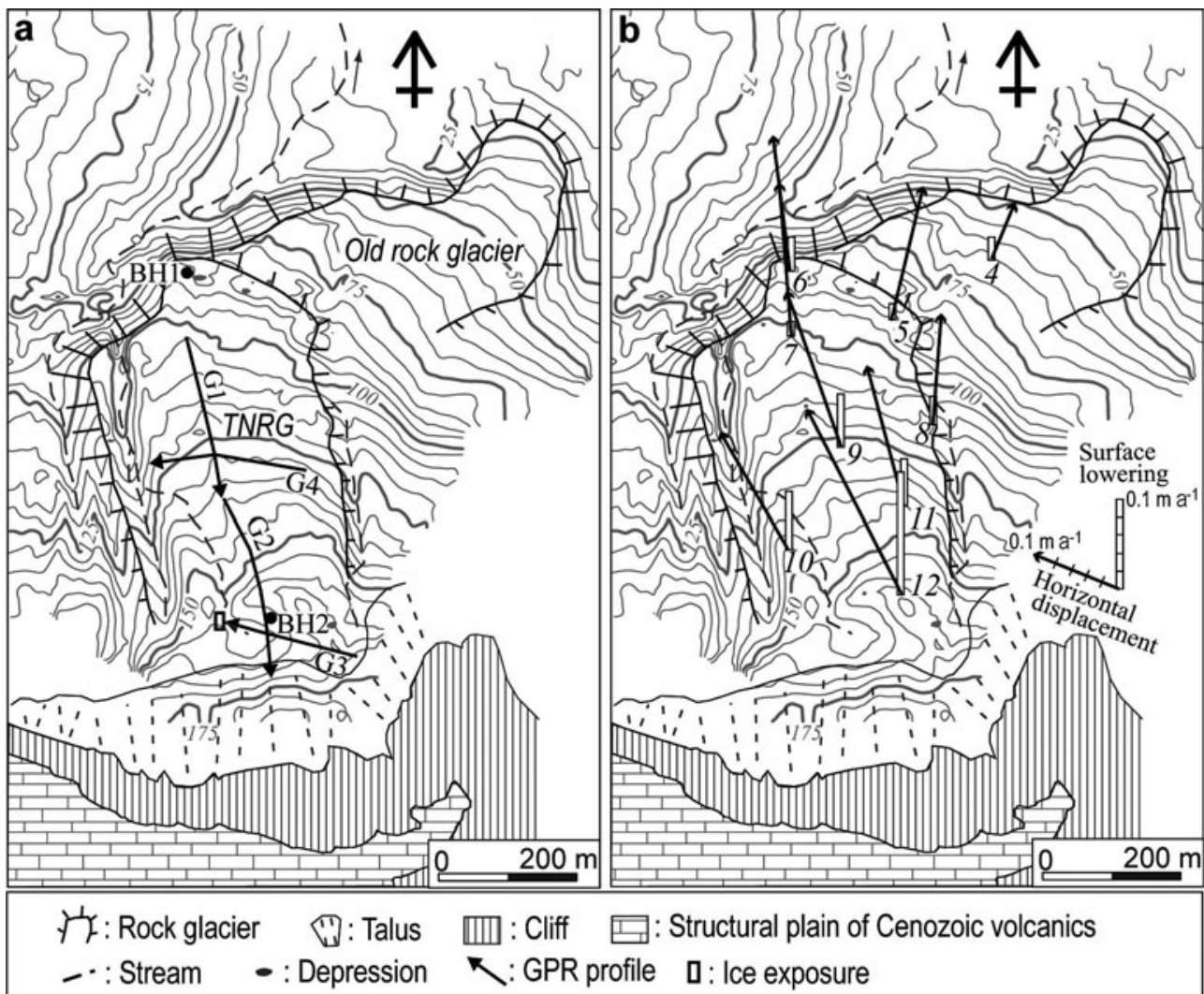

Fig. 3. (a) Location of the GPR profiles, boreholes and ice exposure, and (b) surface movements from 2001 to 2004 on TNRG.

given by the empirical formula of Lliboutry (1965, p. 574):

$$
h=\left[\frac{(n+1) u_{0}}{B(\rho g \sin \alpha)^{n}}\right]^{1 /(n+1)},
$$

where $n$ and $B$ are constants in Glen's (1952) flow law for ice; $\rho$ and $g$ are the ice density in $\mathrm{kg} \mathrm{m}^{-3}$ and gravitational acceleration in $\mathrm{ms}^{-2}$, respectively; and $u_{0}$ and $\alpha$ represent horizontal surface movement $\left(\mathrm{m} \mathrm{a}^{-1}\right)$ and surface inclination $\left({ }^{\circ}\right)$, respectively. The best values for moderate valley glaciers are $n=3, B=0.164 \mathrm{a}^{-1} \mathrm{bar}^{-3}$ and $\rho g=$ 0.087 bar m$^{-1}$ (Lliboutry, 1965). The calculated thicknesses at survey points $6,7,9$ and 12 using this empirical formula are 32, 33, 31 and $33 \mathrm{~m}$, respectively (Table 1).

\section{Description of the ice exposure and GPR soundings}

A transverse ridge ran across the center of the ice exposure. The surface layer was a $0.3-0.4 \mathrm{~m}$ thick debris layer composed of sand and angular gravel (Fig. 4). Bubbly ice that had homogeneous crystals $5-6 \mathrm{~mm}$ in diameter lay beneath the debris layer. Debris-rich layers dipped $14^{\circ}$ upglacier in the bubbly ice. The debris-rich layers were composed of bubble-free ice, coarse sand and angular gravel.

An average radar-wave velocity of $0.17 \mathrm{~m} \mathrm{~ns}^{-1}$ was established for the rock glacier interior by the hyperbolic fitting in G2 and G3 (Figs 5b and 6a). We determined the depth of all GPR profiles using this velocity value.

G2 is a longitudinal profile in the upper half of TNRG (Fig. 5b) which runs parallel to the ice exposure. A large transverse ridge, located at approximately $360 \mathrm{~m}$ in the central part of the GPR profile, is connected to the transverse ridge in the ice exposure (Fig. 4). Two clear reflections dip up-glacier at distances of 350 and $360 \mathrm{~m}$. Because the dipping directions of these reflections are similar to those of the debris-rich layers in the ice exposure, we interpreted the main part of G2 to be bubbly ice and the reflections to represent inter-bedded debris-rich layers.

G1 is a longitudinal profile in the lower half of TNRG (Fig. 5a). The profile surface runs across some small transverse ridges and hollows for $60-180 \mathrm{~m}$. Several reflections dip up-glacier at distances from 60 to $180 \mathrm{~m}$. Most of these reflections run toward the small ridges. Based on the interpretation of profile G2, G1 was also considered to consist primarily of bubbly ice with reflections indicating debris-rich layers.

G3 is a transverse profile in the upper section of TNRG (Fig. 6a). The reflections sink toward the profile center from the west end. G3 crosses G2 at a distance of $64 \mathrm{~m}$. Based on the interpretation of profile G2, the main part of G3 is bubbly ice and the reflections are due to debrisrich layers. We identified a strong reflection at distances from 110 to $170 \mathrm{~m}$ and depths of $33-38 \mathrm{~m}$. This reflection likely represents the glacier sole, because the calculated ice thickness at survey point 12, which is located near G3, was $33 \mathrm{~m}$.

G4 was a transverse profile in the middle section of the glacier (Fig. 6b). Syncline reflections are evident in the profile. The syncline axis coincided with the geometric center of TNRG. The bottom of the syncline reached $30 \mathrm{~m}$ or more in depth. G4 crosses G1 at a distance of $84 \mathrm{~m}$. Based on the interpretation of profile G1, G4 likely consists primarily of bubbly ice, with reflections indicating the debris-rich layers. The calculated ice thickness at survey point 9, adjacent to the profile center, is $31 \mathrm{~m}$. Because the bottom of the syncline reflections reaches a depth of $30 \mathrm{~m}$ or more, it is likely that the debris-rich layers are uplifted from the glacier sole. 

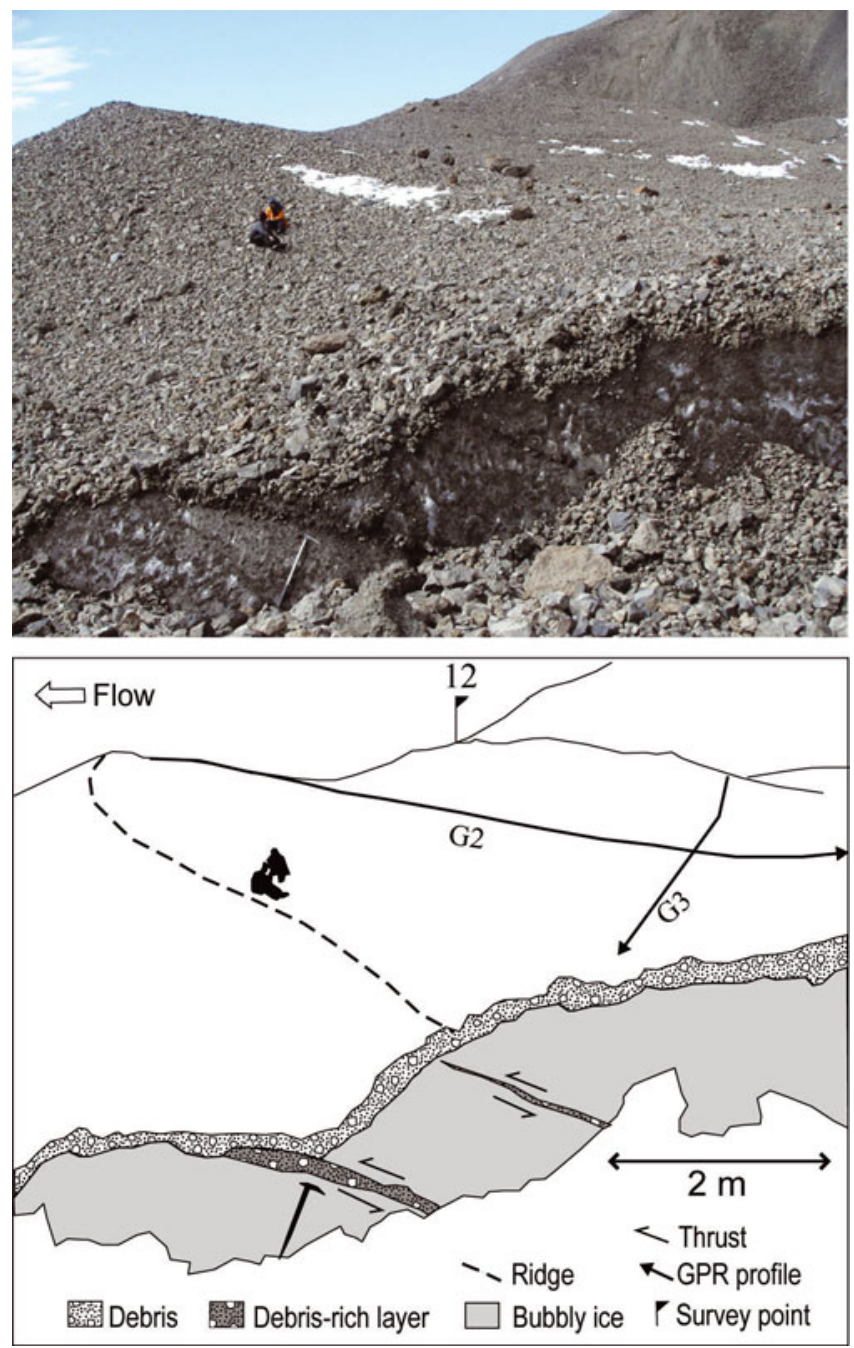

Fig. 4. Stratigraphy of the ice exposure. See Figure 3a for its location.

\section{Limitations of the GPR data}

The apparent reflectivity between these four GPR profiles was different, though profiles G1 and G2 are connected and profiles G4 and G3 cross G1 and G2, respectively. The presence of persistent debris-rich layers is only suggested by GPR profile G4, and possibly by profile G2. The dipping events in profile G1 do not persist laterally for more than $10 \mathrm{~m}$, and in profile G3 they are only evidenced at the western margin of TNRG. It is likely that a large groundcoupling effect, marked reflection within the coarse active layer on the rock glacier and percolation of snow meltwater cause large signal attenuation. This probably causes the different reflectivity between these four GPR profiles.

\section{Ice-core stratigraphy and borehole temperature profiles}

The surface layer of ice core $\mathrm{BH} 1$ is a $0.7 \mathrm{~m}$ thick debris layer composed of coarse sand and angular gravel (Fig. 7). We found frozen debris at depths of $0.6-0.7 \mathrm{~m}$. The frozen debris has a few visible ice lenses. Bubbly ice lies beneath the surface debris layer. The bubbly ice has homogeneous crystals $5-10 \mathrm{~mm}$ in diameter. There is a debris-rich layer, composed of bubble-free ice, coarse sand and angular gravel, at depths of $2.8-3.2 \mathrm{~m}$. Borehole temperatures are positive at depths of $0.1-0.6 \mathrm{~m}$, but negative at depths of $>0.7 \mathrm{~m}$.

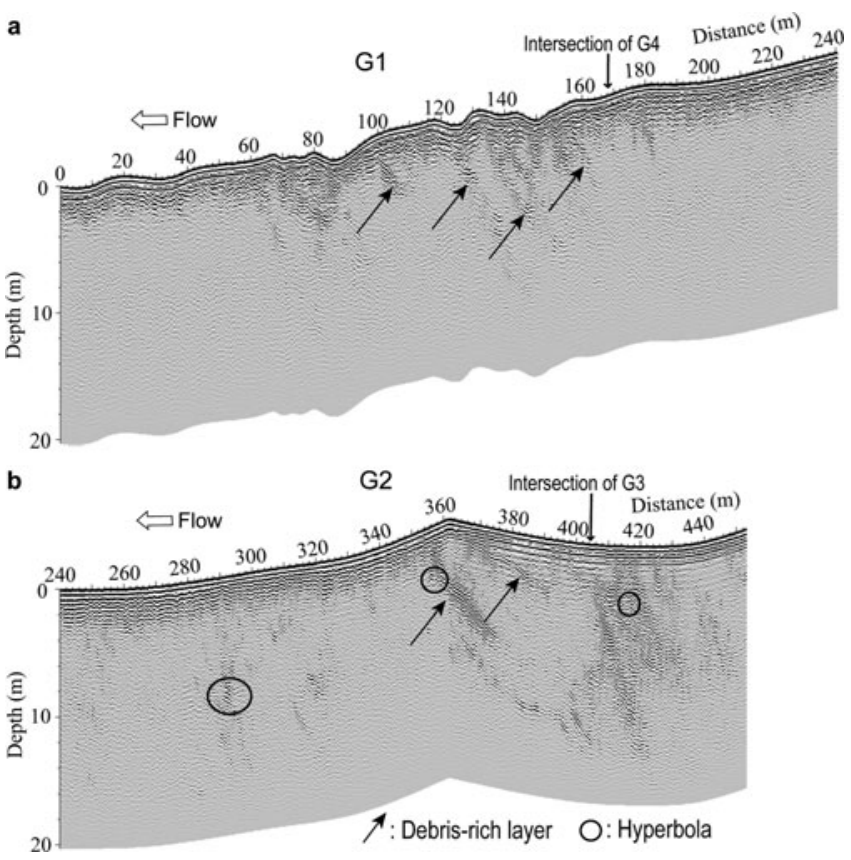

Fig. 5. Longitudinal GPR profiles of TNRG: (a) lower half of the GPR profile G1; and (b) upper half of the GPR profile G2. Vertical exaggeration is $4: 1$.

The top $0.5 \mathrm{~m}$ of $\mathrm{BH} 2$ is new snow and granular snow layers (Fig. 7). Bubbly ice, consisting of homogeneous crystals $5-10 \mathrm{~mm}$ in diameter, lies beneath the snow layers. Two thin $(0.02-0.03 \mathrm{~m})$ debris-rich layers are interposed in the bubbly ice at depths of 0.65 and $1.0 \mathrm{~m}$. The borehole temperatures are all $0^{\circ} \mathrm{C}$ at depths of $0-2 \mathrm{~m}$. The stratigraphy of these boreholes also shows that the rock glacier consists primarily of bubbly ice with debris-rich layers. Borehole temperatures show that the surface ice temperature in the upper part rises to the melting point during summer.

\section{Rock glacier dynamics and internal structure}

The stratigraphy of the ice exposures shows that the internal ice beneath the surface debris cover is bubbly, with interbedded debris-rich layers that dip $14^{\circ}$ up-glacier. Debris-rich layers dipping up-glacier are also identified in the longitudinal GPR profiles. Syncline structures are identified in the transverse GPR profile. The schematic diagram in Figure 8 illustrates the internal structure of TNRG based on stratigraphy from the GPR, the ice exposure and the ice cores. The internal ice structure (shear planes) of a valley glacier resembles 'nested spoons' because of ice modification by strain during flow (e.g. Hooke and Hudleston, 1978). The internal structure of TNRG also resembles 'nested spoons', suggesting that this rock glacier motion is controlled by shear movement, which is common in valley glaciers. This structure has also been demonstrated for Lachman II rock glacier, based on stratigraphy of ice exposures by Strelin and Sone (1998).

GPR soundings have been carried out on some talusderived rock glaciers in Svalbard (Berthling and others, 2000; Isaksen and others, 2000). Berthling and others (2000) used GPR to investigate internal structures in four rock glaciers on Prins Karls Forland, western Svalbard. In the longitudinal GPR profiles, reflections were parallel to the surface in the upper parts of the talus cones above the rock glaciers, while further down towards the rock glaciers the 


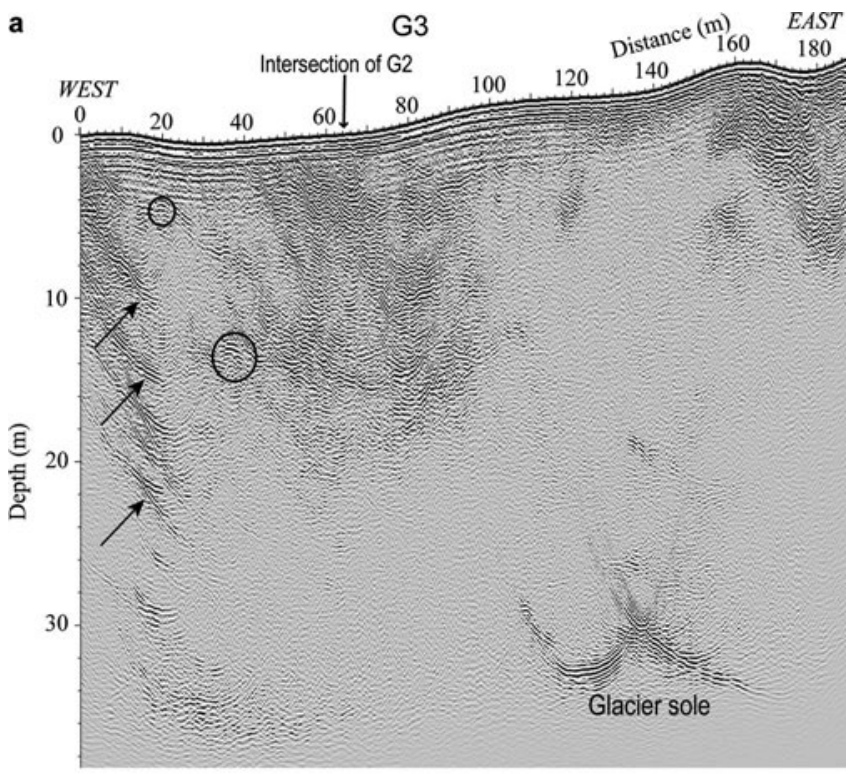

b
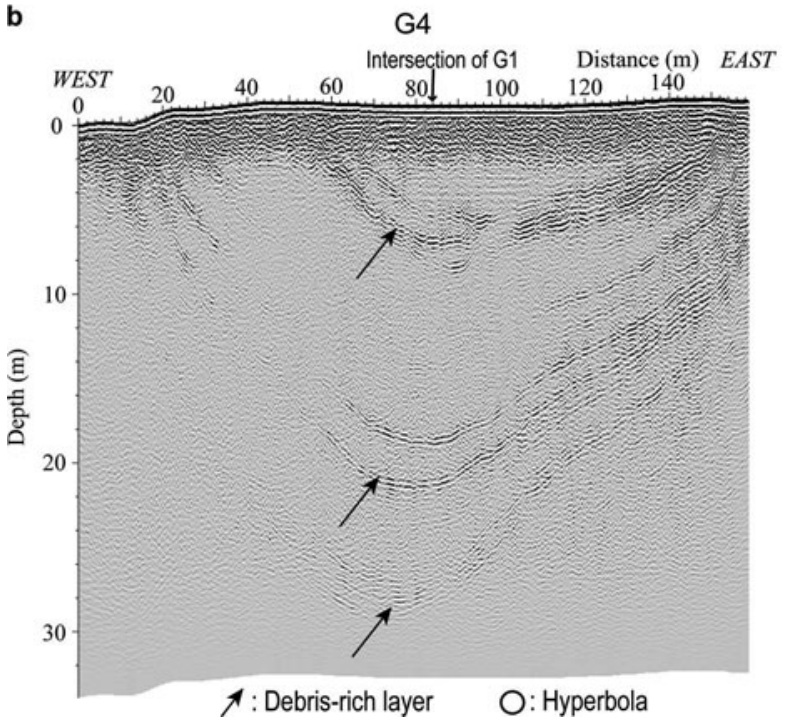

Fig. 6. Transverse GPR profiles of the rock glacier: (a) upper section (G3); and (b) middle section (G4). Vertical exaggeration is $4: 1$.

reflections started to slant up against the surface slope. They estimated by common-midpoint sounding that the radar velocity was $0.14 \mathrm{~m} \mathrm{~ns}^{-1}$. Isaksen and others (2000) carried out GPR investigations on Hiorthfjellet rock glacier near Longyearbyen, Svalbard. They also found that reflections were parallel to the surface in the upper parts of the rock glaciers, while the reflections dipped up-glacier in the middle and lower parts. These studies suggested that layering structures parallel to the surface were likely formed by accumulation of seasonal snow that was buried and compacted by falling rocks and boulders. This mechanism of ice formation is believed to be the most important accumulation process for the talus-derived rock glaciers. Since layering structures parallel to the surface were not found in the upper part and the internal structure resembled that of a valley glacier, we conclude that TNRG is a glacier-derived rock glacier.

Reflections, interpreted as indicators of inter-bedded debris-rich layers, ran toward the transverse ridges in the exposed ice (Fig. 4) and in the longitudinal GPR profiles (Fig. 5). This pattern indicates that transverse ridge formation

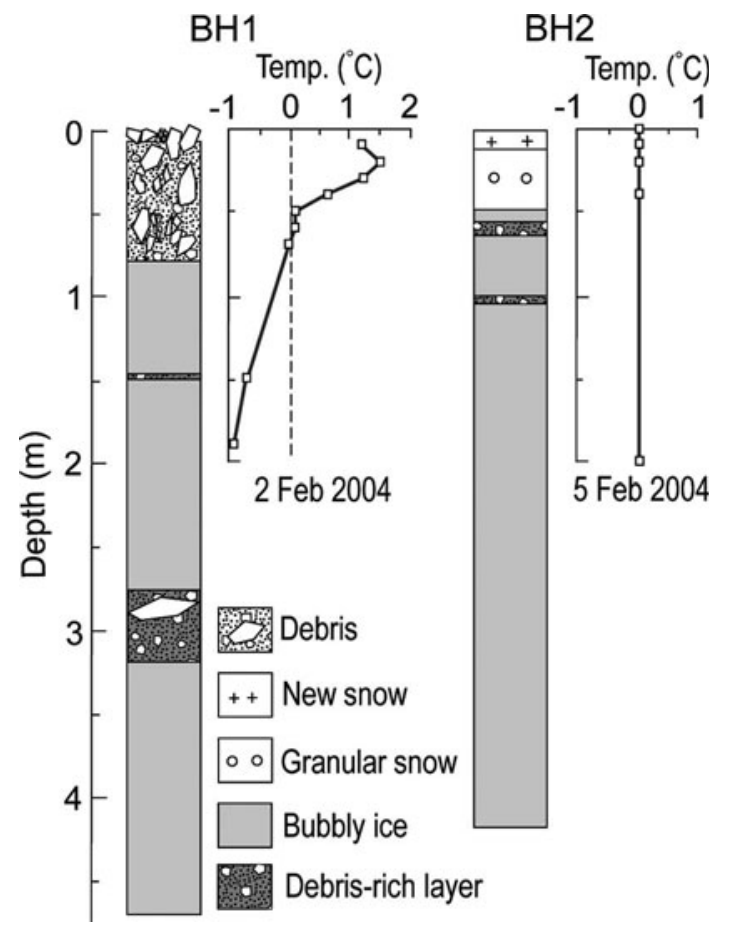

Fig. 7. Stratigraphy and temperatures of boreholes $\mathrm{BH} 1$ and $\mathrm{BH} 2$. See Figure 3a for borehole locations.

is related to the formation of debris-rich layers. Furthermore, the debris-rich layers and movement of the rock glacier suggest a mechanism for the development of the transverse ridges on the rock glacier. Our geodetic survey confirmed that flow velocities decreased toward the lower part of the rock glacier. Such heterogeneous movement will cause longitudinal compression within the rock glacier and form thrusts in the internal ice, as in subpolar valley glaciers (e.g. Hambrey and Müller, 1978; Hambrey and others, 1999). These thrust movements create inter-bedded debris-rich layers by uplifting basal ice and debris from the bottom of the rock glacier (Chinn and Dillon, 1987; Strelin and Sone, 1998), and the debris-rich layers are extruded to the surface. The pressure of the upstream ice against the downstream ice bends the surface layers, forming the transverse ridges seen on the surface of the rock glacier (Fig. 8).

\section{CONCLUSIONS}

1. The stratigraphic analyses of the GPR and the ice exposure both show that despite the talus-derived appearance of TNRG, it has an internal structure similar to that of the 'nested spoons' structure common in valley glaciers. This result indicates that the motion of the rock glacier is controlled by shear, common in glaciers.

2. Since the internal structure of TNRG is similar to that of valley glaciers and has no features of talus-derived rock glaciers, TNRG is believed to be glacier-derived.

3. Reflections, interpreted as being indicative of debris-rich layers, run toward the transverse ridges in the longitudinal GPR profiles. It is likely they were formed by thrust movements within TNRG. These thrust movements will create inter-bedded debris-rich layers by uplifting basal ice and debris from the bottom of the rock glacier, 


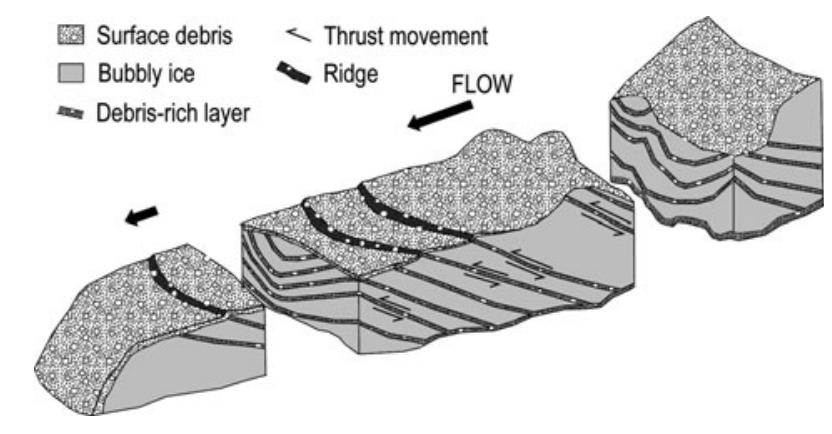

Fig. 8. Schematic diagram of the dynamics and internal structure of the rock glacier.

causing the debris-rich layers to extrude to the surface. The movement of the upstream ice pushing slowly against downstream ice bends the surface layers of the rock glacier, forming the transverse ridges.

\section{ACKNOWLEDGEMENTS}

We are grateful to the Instituto Antártico Argentino (IAA) and Fuerza Aérea Argentina for logistical and technical support on James Ross Island and at Marambio base. We also thank A. Sobral (Centro Austral de Investigaciones Científicas) for expert assistance in the field. This work was partly supported by PICTO 2002 7-11573 of Secretaría de Ciencid y Técnica de la Universidad Nacionale de Córdoba (SECyT)-IAA (principal investigator: J. Strelin) and by a grant from the Ministry of Education, Culture, Sports, Science and Technology, Japan (principal investigator: K. Fukui, 15-1492).

\section{REFERENCES}

Baker, V.R. 2003. Planetary science: icy martian mysteries. Nature, 426(6968), 779-780.

Barsch, D. 1996. Rockglaciers: indicators for the present and former geoecology in high mountain environments. Berlin, etc., Springer-Verlag.

Benn, D.I. and D.J.A. Evans. 1998. Glaciers and glaciation. London, Arnold.

Berthling, I., B. Etzelmüller, K. Isaksen and J.L. Sollid. 2000. Rock glaciers on Prins Karls Forland. II: GPR soundings and the development of internal structures. Permafrost Periglac. Process., 11(4), 357-369.

Bibby, J.S. 1966. The stratigraphy of part of north-east Graham Land and the James Ross Island Group. Br. Antarct. Surv. Sc. Rep., 53.

Chinn, T.J.H. and A. Dillon. 1987. Observations on a debriscovered polar glacier "Whiskey Glacier", James Ross Island, Antarctic Peninsula, Antarctica. J. Glaciol., 33(115), 300-310.

Colaprete, A. and B.M. Jakosky. 1998. Ice flow and rock glaciers on Mars. J. Geophys. Res., 103(E3), 5897-5909.

Degenhardt, J.J. and J.R. Giardino. 2003. Subsurface investigation of a rock glacier using ground-penetrating radar: implications for locating stored water on Mars. J. Geophys. Res., 108(E4), 8036. (10.1029/2002JE001888.)

Fukuda, M., J.A. Strelin, K. Shimokawa, N. Takahashi, T. Sone and D. Trombotto. 1992. Permafrost occurrence of Seymour Island and James Ross Island, Antarctic Peninsula region. In
Yoshida, Y., K. Kaminuma and K. Shiraishi, eds. Recent progress in Antarctic earth sciences. Tokyo, Terra Scientific Publishing Co., 745-750.

Glen, J.W. 1952. Experiments on the deformation of ice. J. Glaciol., 2(12), 111-114.

Haeberli, W. and 10 others. 2008. Permafrost creep and rock glacier dynamics. Permafrost Periglac. Process., 17(3), 189-214.

Hambrey, M.J. and F. Müller. 1978. Structures and ice deformation in the White Glacier, Axel Heiberg Island, Northwest Territories, Canada. J. Glaciol., 20(82), 41-66.

Hambrey, M.J., M.R. Bennett, J.A. Dowdeswell, N.F. Glasser and D. Huddart. 1999. Debris entrainment and transfer in polythermal valley glaciers. J. Glaciol., 45(149), 69-86.

Hjort, C., O. Ingólfsson, P. Möller and J.M. Lirio. 1997. Holocene glacial history and sea level changes on James Ross Island, Antarctic Peninsula. J. Quat. Sci., 12(4), 259-273.

Hooke, R.LeB. and P.J. Hudleston. 1978. Origin of foliation in glaciers. J. Glaciol., 20(83), 285-299.

Humlum, O. 1998. The climatic significance of rock glaciers. Permafrost Periglac. Process., 9(4), 375-395.

Humlum, O. 2000. The geomorphic significance of rock glaciers: estimates of rock glacier debris volumes and headwall recession rates in West Greenland. Geomorphology, 35(1-2), 41-67.

Isaksen, K., R.S. Ødegård, T. Eiken and J.L. Sollid. 2000. Composition, flow and development of two tongue-shaped rock glaciers in the permafrost of Svalbard. Permafrost Periglac. Process., 11(3), 241-257.

Lliboutry, L. 1965. Traité de glaciologie. Tome II: Glaciers, variations du climat, sols gelés. Paris, Masson et Cie.

Lundqvist, J., M. Lilliesköld and K. Östmark. 1995. Glacial and periglacial deposits of the Tumbledown Cliffs area, James Ross Island, West Antarctica. Geomorphology, 11(3), 205-214.

Potter, N., Jr. 1972. Ice-cored rock glacier, Galena Creek, northern Absaroka Mountains, Wyoming. Geol. Soc. Am. Bull., 83(10), 3025-3057.

Sone, T. and J.A. Strelin. 1997. Air temperature conditions and climatic-geomorphological characteristics of James Ross Island, Antarctic Peninsula. In Rinaldi, C.A., ed. Cuartas Jornadas de communicaciones sobre investigaciones Antárticas. Buenos Aires, Instituto Antártico Argentino. Dirección Nacional del Antártico, 372-377.

Strelin, J. and E.C. Malagnino. 1992. Geomorfología de la Isla James Ross. In Rinaldi, C.A., ed. Geología de la Isla James Ross, Antártida. Buenos Aires, Instituto Antártico Argentino. Dirección Nacional del Antártico, 7-36.

Strelin, J.A. and T. Sone. 1998. Rock glaciers on James Ross Island, Antarctica. In Lewkowicz, A.G. and M. Allard, eds. Proceedings of the Seventh International Permafrost Conference, 23-27 June 1998, Yellowknife, N.W.T., Canada. Laval, Université Laval, Centre d'Etudes Nordiques. 1027-1032.

Strelin, J.A., T. Sone, J. Mori, C.A. Torielli and T. Nakamura. 2006. New data related to Holocene landform development and climatic change from James Ross Island, Antarctic Peninsula. In Fütterer, D.K., D. Damaske, G. Kleinschmidt, H. Miller and F. Tessensohn, eds. Antarctica: contributions to global earth sciences. Berlin, etc., Springer Verlag, 455-460.

Wahrhaftig, C. and A. Cox. 1959. Rock glaciers in the Alaska Range. Geol. Soc. Am. Bull., 70(4), 383-436.

Whalley, W.B. and F. Azizi. 2003. Rock glaciers and protalus landforms: analogous forms and ice sources on Earth and Mars. J. Geophys. Res., 108(E4), 8032. (10.1029/2002JE001864.)

Whalley, W.B. and H.E. Martin. 1992. Rock glaciers: II models and mechanisms. Progr. Phys. Geogr., 16(2), 127-186. 